\title{
Development and Evaluation of Students' Mathematics Achievement Model through Structural Equation Modelling
}

\author{
Zulkifley Mohamed, Rosmah Ramli, Abu Kassim Ali Musa, Nor Hashimah Abu Bakar, Faiz \\ Zulkifli
}

\begin{abstract}
The used of teaching kit among teachers plays an important role in enhancing student performance, especially for the primary students. The study aimed at developing and evaluating students' mathematics achievement model which consists of mathematical process skills, teaching kit and mathematics achievement latent variables of Year Three Primary School Students. Cluster random sampling was used to select 98 students from 15 schools in the North Kinta District in Perak, Malaysia. Mathematics teachers from each school were trained by researchers in the workshop in utilization of teaching kit. The Partial Least Squares approach in Structural Equation Modelling (PLS-SEM) was utilized in developing and evaluating the model as the size of the sample was too small. The study indicates that there was significant relationship between mathematical process skills, teaching kit and mathematics achievement latent variables in the developed model. Apart of mathematical process skills, teaching kit also a significant contribution factor to students' mathematics achievement in the structural model. The study also showed that the mathematical process skills was attributed by teaching kit. In conclusion, this study had successfully developed and evaluated students' achievement model based on mathematical process skills and the utilization of teaching kit. This study implied that apart from others factor, mathematical process skills and utilization of teaching kit are also contributing a different perspective to the process of students' learning and achievements.
\end{abstract}

Keywords: Mathematical process skills, PLS-SEM, students' mathematics achievement, teaching kit.

\section{INTRODUCTION}

The Education Revolution 4.0 demands teachers to improve their teaching and learning (TaL) skills to face the ever-increasing era of globalization. Teachers have a very important role and responsibility in improving students' achievement to higher levels [1]. Among the current responsibilities of teachers are to equip themselves with a variety of skills and competencies such as enhancing teaching methods in the classroom by utilizing technology, applying harmonious $\mathrm{TaL}$ environment, and establishing a good relationship between teacher and students [2]. Without upgrading teachers' skills and competencies, TaL quality will be lowered. Furthermore, learning of science,

Revised Manuscript Received on September 14, 2019.

Zulkifley Mohamed, Department of Mathematics, Faculty of Science and Mathematics, Universiti Pendidikan Sultan Idris, 35900 Tanjong Malim, Perak, Malaysia. Email: zulkifley@fsmt.ipsi.edu.my

Rosmah Ramli, Department of Mathematics, IPG Ipoh Campus, 31150 Hulu Kinta, Perak, Malaysia.

Abu Kassim Ali Musa, Department of Educational Technology, IPG Ipoh Campus, 31150 Hulu Kinta, Perak, Malaysia.

Norhashimah Abu Bakar, Department of Mathematics, IPG Ipoh Campus, 31150 Hulu Kinta, Perak, Malaysia.

Faiz Zulkifli, Faculty of Computer and Mathematical Sciences,Universiti Teknologi MARA Perak Branch, Tapah Campus, 35400 TapahRoad, Perak, Malaysia. technology, engineering, and mathematics (STEM) is not far away from its implementation problem in school as it is considered less interesting and consistent. STEM is a key element in science-related programs of the 21 st century [3].

In the context of $\mathrm{TaL}$ of mathematics, teachers need to be more creative and critical when planning their lessons. Teaching method must be in line with the ability of the students. Teachers need to actively engage students in the $\mathrm{TaL}$ and this requires a high level of teaching skills. The traditional pattern and chalk and talk approach used by teachers customarily in TaL is not in line with the desiderata of today's students. The traditional approach is more teacher-centered rather than student-centered. Current educational goals in the Primary School Standard Curriculum accentuated on the teachers to encourage students to inspirit in the TaL process. Additionally, it also aims to attract students to focus actively and exhilarate the students in the daily learning process. The student-centered learning techniques fixate on 'hands-on' and 'minds-on' techniques, these will have a more effective impact on achieving the goals of mathematical education itself. Learning will withal occur when what is edified gives meaning to the students [4].

The use of teaching kit in school has a good impact on the academic excellence of the students and the teaching process of the teachers. This study was conducted by [5], [6]. The two findings revealed that the utilization of teaching kit during the TaL process could allow students to concentrate on the lesson. In addition, TaL that utilizes teaching kit can improve the students' memory of the lessons learned. Consequently, students can visually memorize the lesson based on teaching kit utilized by teachers. This was explicated by [7] that the visual memory method is the best way for students to recall rote.

While in the context of modelling of students' achievement, in [8] analyzes the relationship between the mathematics grade and the three basic cognitive abilities (inhibition, working memory, and reasoning) during elementary school. In [9] investigates the direct and indirect effects of a number noncognitive constructs on the mathematical problem solving among students. In [10] studies the noncognitive domains of academic self-beliefs, motivation, learning strategy, and attitudes toward school that linked to the mathematics achievement scores. In [11] investigates relations between emotional support and mathematical discourse, instructional support and 


\section{DEVELOPMENT AND EVALUATION OF STUDENTS' MATHEMATICS ACHIEVEMENT MODEL THROUGH STRUCTURAL EQUATION MODELLING}

mathematical tasks, and classroom organization and mathematical coherence. While, in [12] revealed that wellmanaged classroom and learning support were positively associated with higher performance in math. This study fixates on the process skills, instructional fortifies and students' achievement. The study seeks to determine the teaching kits towards students' mathematics achievement by using PLS-SEM.

\section{PURPOSE OF THE STUDY}

In developing the mathematical process skills, teaching kit and students' mathematics achievement model, the study reviews the related literature on mathematical process skills and the utilization of teaching kit in TaL. Among the major factors affecting mathematics achievement revealed by [13][15] was problem solving skills. While, in [16]-[18] found that reasoning skills as the major factors affecting mathematics achievement. In [19], [20] proved that there are positive relationships between problem solving and reasoning skills. Hence, this study is aimed at developing and evaluating a structural equation modelling that demonstrate the relationship between mathematical process skills, the teaching kit and students' mathematics achievement.

\section{METHODOLOGY}

The study population consists of Year three students attending primary schools. Cluster random sampling was utilized to select 98 students from 15 schools in the North Kinta district, Perak, Malaysia. Mathematics teachers from each school were trained by researchers in the workshop to improve TaL using teaching kit. SmartPLS 3.0 software was used in analyzing the data.

\section{A. Students' mathematics achievement construct}

The students' mathematics achievement construct developed in this study was used to assess students' mathematics achievement. A total of four items was tested in this construct comprises students' attainment level in problem solving, reasoning, connections, representations and communication skills. The score is relying on the number of questions correctly answered. The construct reliability coefficient $(\alpha)$ shows the value of $0.947(n=98)$.

\section{B. Mathematical process skills}

A mathematical process skill was composed of five constructs namely problem solving, reasoning, connections, representations, and communication skills. The mathematical process skills constructs developed by [22] were used in this study.

\section{Problem solving skills}

The problem-solving skills construct consisted of six items. Considering the problem solving stages described by [22], students were asked to explain the steps in solving the problems for each question included in the construct; to describe the steps in solving the problems, to solve routine problems with guidance; to solve routine calculation problems unguided, to solve involute routine problems; to solve involute routine problems by utilizing several options; relationship between mathematical process skills and

and to solve non-routine problems ingeniously and innovatively. The responses given to the questions in the constructs were scored in values varying between 1 and 5 . The Cronbach Alpha reliability coefficient of the problemsolving skills construct was calculated to be $0.847(n=98)$.

\section{Reasoning skills}

In order to measure the reasoning skills. The students were asked to respond to the questions in the constructs. The reasoning skills construct was composed of six items. The students were asked to justify logically mathematical activities: with guidance, without guidance, without guidance involving a calculation, without guidance involving more than one calculation, involving routine problem, involving non-routine, creative and innovative problem solving. The responses given to the questions in the constructs were scored in values varying between 1 and 5 . The reliability coefficient $(\alpha)$ of the reasoning skills construct was calculated to be $0.921(n=98)$.

\section{E. Connections skills}

The connections skills construct was composed of five items. Students were asked to make a connection between (i) the topics learned with other topics and daily life unguided; (ii) the concepts and procedures for solving mathematical sentence problems; (iii) the concepts and procedures for solving routine day-to-day problems; (iv) the concepts and procedures for solving routine day-to-day problems using multiple strategies, and (v) the concepts and procedures in solving non-routine day-to-day problems ingeniously and innovatively. The answers given in the constructs to the questions were scored in values ranging from 1 to 5 . The reliability coefficient $(\alpha)$ of the connection's skills construct was calculated to be 0.921 $(n=98)$.

\section{F. Representations skills}

The representations skills construct was composed of five items. Students were asked to use representations skills to show mathematical understanding without guidance, to explain mathematical concept and procedures, to solve dayto-day routine problems, to solve day-to-day routine problem using various strategies, and to solve day-to-day non routine problems creatively and innovatively. The answers given in the constructs to the questions were scored in values ranging from 1 to 5 . The reliability coefficient $(\alpha)$ of the representation's skills construct was calculated to be $0.892(\mathrm{n}=98)$.

\section{G. Communication skills}

The communication skills construct was composed of five items. Students were asked to state mathematical idea verbally or in written form using mathematical symbol or visual representation, to explain mathematical idea verbally or in written form using mathematical symbol or visual representation, to use correct mathematical language, symbol or visual representation, to explain mathematical idea systematically using correct mathematical language, 
symbol or visual representation in solving routine problems, and to explain mathematical ideas systematically using correct mathematical language, symbol or visual representation in solving non-routine problems ingeniously and innovatively. The answers given in the constructs to the questions were scored in values ranging from 1 to 5 . The reliability coefficient $(\alpha)$ of the communication skills construct shows the value $0.906(n=98)$.

\section{H. Usability of teaching kit}

The usability construct of teaching kit was developed by the researcher. The study engaged experts in mathematics and mathematical education to validate the items in the constructs. Assessment by experts is necessary to ensure the accuracy of the construct and clarity of content [23]. The panel of experts in the study consisted of two mathematicians, a lecturer and two excellent mathematics primary school teachers who had more than 10 years of experience teaching mathematics. All appointed panels have been briefed on the background of the study, the involved constructs and the task of reviewing the items being constructed. They have been given an Assessment Instrument Specialist Revision Form to make corrections, comment and suggestion on the items that are inadequate to the constructs. The final version of the constructs consists of six items. The questions on usability of the constructs were the utilization of teaching kit can enhance mathematical: problem solving, reasoning, connections, representations, communication, and overall process skills. The answers given in the constructs to the questions were rated in values ranging from 1 to 5 . The reliability coefficient $(\alpha)$ of the teaching kit construct was calculated to be $0.928(n=98)$.

\section{RESULTS AND DISCUSSION}

\section{A. Students' achievement model}

The research model involves the measurement and structural model. In this study, there were seven measurement models that describes the relationship between latent variables and observed variables. The latent variables with their (observed variables) exhibit in Fig. 1 were problem solving (PS1-PS6), reasoning (RS1-RS6), connections (CN1-CN5), representations (RP1-RP5), communication (CM1-CM5), teaching kit (TK1-TK6), and students' mathematics achievement (AL1-AL4). The structural model describes the relationship between variables that we are interested in. The teaching kit and mathematical process skills; mathematical process skills and students' achievement; problem solving, reasoning, connections, representations, and communication relationship were also exhibited in Fig. 2 structural equation modelling.

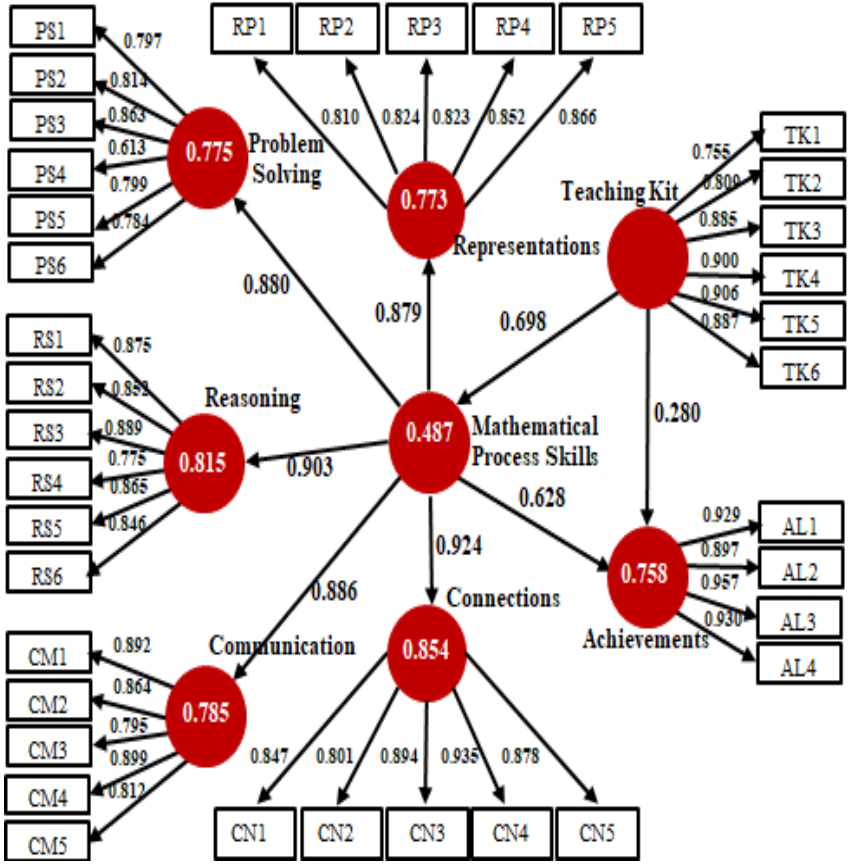

Fig. 1: PLS-SEM of the students' mathematics achievement model

B. Assessing the reliability and validity of the measurement model

As stated by [24], the measurement model in PLS-SEM can be assessed by means of its (i) Alpha Cronbach $(\alpha)$ and Composite Reliability (CR) values for internal consistency; (ii) outer loading value for reliability of each observed variable; (iii) Average Variance Extracted (AVE) value for convergence validity; and (iv) Fornell-Larcker and Heterotrait-Monotrait (HTMT) ratio for discriminant validity.

The results in Table 1 indicate that all the Alpha Cronbach $(\alpha)$ and CR value of seven latent constructs were more than 0.70 . This designates that the observed variables in each latent construct were ample to quantify the respective constructs as suggested by [25]. The outer loadings value for each observed variable for reliability assessment were also found to be greater than 0.70. This indicates that each observed variable is sufficient to represent the constructs as stated by [25].

Four observed variables (PS4, PS5, PS6 and RS4) were eliminated to meet the evaluation criteria of the measurement model even though the outer loading of the respective observed variables were greater than 0.70 .

\section{Validity of the constructs}

Table 1 shows that the AVE value for each construct exceeded 0.50 . This indicates that the validity was achieved for each construct as recommended by [26]. 


\section{DEVELOPMENT AND EVALUATION OF STUDENTS' MATHEMATICS ACHIEVEMENT MODEL THROUGH STRUCTURAL EQUATION MODELLING}

Table 1: Assessment of measurement model

\begin{tabular}{|c|c|c|c|c|c|c|c|}
\hline Construct & Item & Loading & $\begin{array}{l}\text { Indicator } \\
\text { Reliability }\end{array}$ & $a$ & CR & AVE & Discrimination \\
\hline Acceptance Limit & & $>0.708$ & $>0.501$ & $>0.700$ & $>0.700$ & $>0.500$ & \\
\hline \multirow[t]{3}{*}{ Problem Solving } & PS1 & 0.812 & 0.659 & \multirow{3}{*}{0.847} & \multirow[t]{3}{*}{0.908} & \multirow[t]{3}{*}{0.768} & \multirow[t]{3}{*}{ Yes } \\
\hline & PS2 & 0.889 & 0.790 & & & & \\
\hline & PS3 & 0.925 & 0.856 & & & & \\
\hline \multirow[t]{5}{*}{ Reasoning } & RS1 & 0.856 & 0.732 & \multirow[t]{5}{*}{0.921} & \multirow[t]{5}{*}{0.940} & \multirow[t]{5}{*}{0.759} & \multirow[t]{5}{*}{ Yes } \\
\hline & RS2 & 0.883 & 0.780 & & & & \\
\hline & RS3 & 0.893 & 0.797 & & & & \\
\hline & RS5 & 0.872 & 0.760 & & & & \\
\hline & RS6 & 0.853 & 0.727 & & & & \\
\hline \multirow[t]{5}{*}{ Connections } & $\mathrm{CN1}$ & 0.847 & 0.717 & \multirow[t]{5}{*}{0.921} & \multirow[t]{5}{*}{0.941} & \multirow[t]{5}{*}{0.761} & \multirow[t]{5}{*}{ Yes } \\
\hline & $\mathrm{CN} 2$ & 0.801 & 0.642 & & & & \\
\hline & $\mathrm{CN} 3$ & 0.894 & 0.799 & & & & \\
\hline & $\mathrm{CN} 4$ & 0.935 & 0.874 & & & & \\
\hline & CN5 & 0.878 & 0.771 & & & & \\
\hline \multirow[t]{5}{*}{ Representations } & RP1 & 0.810 & 0.656 & \multirow[t]{5}{*}{0.892} & \multirow[t]{5}{*}{0.920} & \multirow[t]{5}{*}{0.698} & \multirow[t]{5}{*}{ Yes } \\
\hline & RP2 & 0.824 & 0.679 & & & & \\
\hline & RP3 & 0.823 & 0.677 & & & & \\
\hline & RP4 & 0.853 & 0.728 & & & & \\
\hline & RP5 & 0.866 & 0.750 & & & & \\
\hline \multirow[t]{5}{*}{ Communication } & CM1 & 0.892 & 0.796 & \multirow[t]{5}{*}{0.906} & \multirow[t]{5}{*}{0.940} & \multirow[t]{5}{*}{0.759} & \multirow[t]{5}{*}{ Yes } \\
\hline & CM2 & 0.864 & 0.746 & & & & \\
\hline & CM3 & 0.795 & 0.632 & & & & \\
\hline & CM4 & 0.899 & 0.808 & & & & \\
\hline & CM5 & 0.811 & 0.658 & & & & \\
\hline \multirow[t]{6}{*}{ Teaching Kits } & TK1 & 0.755 & 0.570 & \multirow[t]{6}{*}{0.928} & \multirow[t]{6}{*}{0.944} & 0.737 & Yes \\
\hline & TK2 & 0.809 & 0.654 & & & & \\
\hline & TK3 & 0.885 & 0.783 & & & & \\
\hline & TK4 & 0.900 & 0.810 & & & & \\
\hline & TK5 & 0.906 & 0.820 & & & & \\
\hline & TK6 & 0.887 & 0.787 & & & & \\
\hline Achievements & AL1 & 0.929 & 0.863 & 0.947 & 0.962 & 0.862 & Yes \\
\hline & AL2 & 0.897 & 0.805 & & & & \\
\hline & $\mathrm{ALL} 3$ & 0.957 & 0.916 & & & & \\
\hline & AL4 & 0.930 & 0.865 & & & & \\
\hline
\end{tabular}

The square root of the AVE was compared with the coefficient of correlation of each construct in the row and column to assess the discriminant validity as shown in Table 2. The results showed that the coefficient of correlation of each construct in the row and column was lower than the square root of the AVE. This indicates that the discriminant validity for all seven constructs is achieved.

Table 2: Fornell-Larcker Criterion on discriminant validity

\begin{tabular}{|l|l|l|l|l|l|l|l|}
\hline Construct & PS & RS & CN & RP & CM & TK & AC \\
\hline Problem Solving & $\mathbf{0 . 8 7 7}$ & & & & & & \\
\hline Reasoning & 0.766 & $\mathbf{0 . 8 7 1}$ & & & & & \\
\hline Connections & 0.723 & 0.787 & $\mathbf{0 . 8 7 2}$ & & & & \\
\hline Representations & 0.665 & 0.787 & 0.764 & $\mathbf{0 . 8 3 5}$ & & & \\
\hline Communication & 0.648 & 0.725 & 0.787 & 0.732 & $\mathbf{0 . 8 5 3}$ & & \\
\hline Teaching Kits & 0.439 & 0.469 & 0.606 & 0.546 & 0.801 & $\mathbf{0 . 8 5 9}$ & \\
\hline Achievements & 0.668 & 0.744 & 0.818 & 0.740 & 0.730 & 0.719 & $\mathbf{0 . 9 2 9}$ \\
\hline
\end{tabular}

*Note: Square root of AVE (bold) and the value correlation coefficient

While, the Heterotrait-Monotrait (HTMT) ratio results are shown in Table 3. The coefficient of correlation between constructs is less than 0.90 suggests that all constructs are unique from each other [24], and henceforth the measurement model showed an ample discriminating validity.

Table 3: Heterotrait-Monotrait (HTMT) ratio

\begin{tabular}{|l|c|c|c|c|c|c|c|}
\hline Construct & PS & RS & CN & RP & CM & TK & AC \\
\hline Problem Solving & & & & & & & \\
\hline Rea soning & 0.868 & & & & & & \\
\hline Connections & 0.818 & 0.855 & & & & & \\
\hline Representations & 0.761 & 0.797 & 0.840 & & & & \\
\hline Communication & 0.741 & 0.790 & 0.856 & 0.808 & & & \\
\hline Teaching Kits & 0.486 & 0.499 & 0.644 & 0.595 & 0.867 & & \\
\hline Achievements & 0.746 & 0.797 & 0.876 & 0.805 & 0.787 & 0.760 & \\
\hline
\end{tabular}

In summary, in response to the evaluations based on the criteria proposed by [24], the measurement model is acceptable.

\section{Assessing the structural model}

According to [24], the structural model can be evaluated by assessing the collinearity of the latent variables, the path coefficient, the coefficient of determination (R2), the $f^{2}$ effect size, and the $Q^{2}$ predictive relevancy.

\section{Assessing the collinearity between latent variables}

The Variance Inflation Factor (VIF) value was used to determine the collinearity between latent variables in structural model. The value of not exceeded 5.0 for VIF indicates the absence of collinearity. The result of this study showed that the VIF of all latent variables were less than 5.0, and therefore the collinearity does not exit.

\section{Assessing the path coefficient of the latent variables}

The bootstrapping analysis was designated in PLS-SEM to evaluate the significance of path coefficient of the latent variables. The result of bootstrapping was exhibited in Fig. 2. All the path coefficients of the concern latent variables were statistically significant.

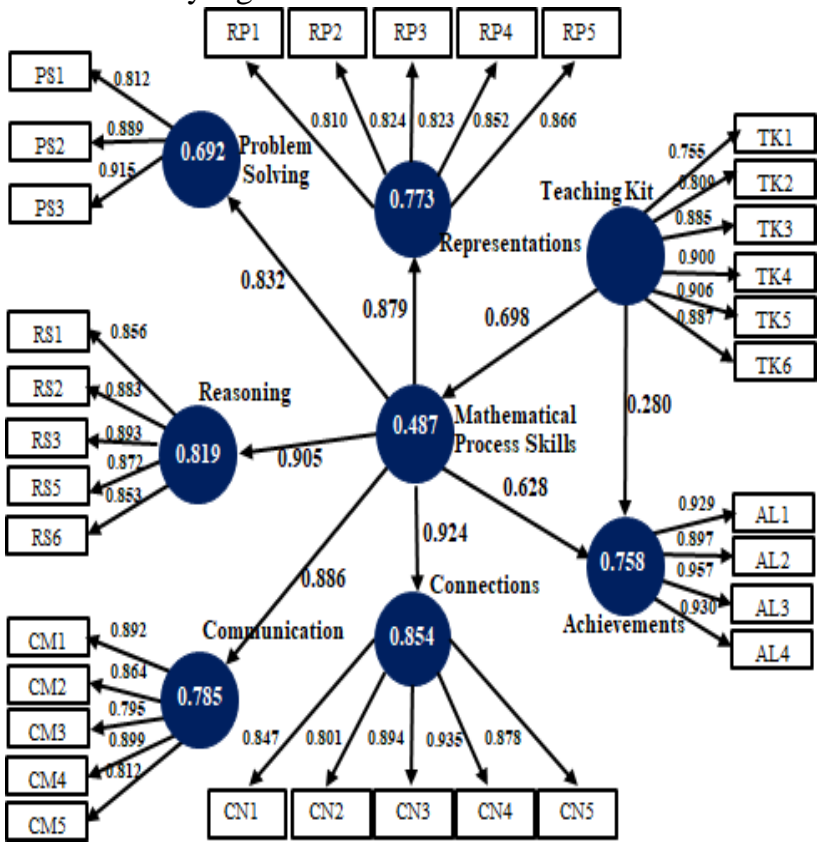

Fig. 2: PLS-SEM Bootstrapping analysis

The standard error (SE) and t-value to indicate the significant relationship between latent variables are presented in Table 4.

Table 4: Assessment of the relevance of relationships between latent variables in the structural model

\begin{tabular}{|l|c|c|c|}
\hline Relationship & Std. beta & SE & $t$-value \\
\hline Mathematical Process Skills ---> Achievements & 0.628 & 0.079 & 7.907 \\
\hline Teaching Kit ---> Achievements & 0.280 & 0.098 & 2.858 \\
\hline Teaching Kit --> Mathematical Process Skills & 0.698 & 0.073 & 9.550 \\
\hline
\end{tabular}

The result revealed that the relationship between (i) mathematical process skills and students' mathematics achievement; (ii) teaching kit and students' mathematics achievement; and (iii) teaching kit and mathematical process skills were statistically significant. This relationship is supported at $\mathrm{p}<0.01$

In addition, this study also demonstrates the result of the significance of the correlation between mathematical process skills and its components. This was shown in Table 5.

Published By:

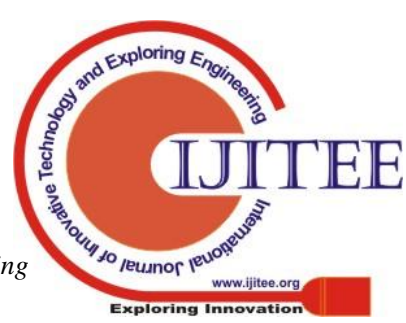


Table 5: Correlation coefficients for the relationship between the components of mathematical process skills

\begin{tabular}{|l|c|c|}
\hline Relationship & Correlation coefficient & $t$-value \\
\hline Mathematical Process skills -> Problem Solving & 0.832 & 14.694 \\
\hline Mathematical Process skills -> Reasoning & 0.905 & 20.593 \\
\hline Mathematical Process skills -> Connections & 0.923 & 23.502 \\
\hline Mathematical Process skills -> Representations & 0.879 & 18.062 \\
\hline Mathematical Process skills - > Communication & 0.886 & 18.722 \\
\hline
\end{tabular}
mathematical process skills and problem solving, reasoning, connections, representations and communication skills respectively are statistically significant. The correlations are supported at $\mathrm{p}<0.001$. This shows that the relevance component is most helpful in explaining the variance value of latent construct of the mathematical process skills.

\section{The coefficient of determination ( 22 value)}

The $R^{2}$ value of dependent variables is assessed to determine the amount of variation in each construct, which are described by the model. The $R^{2}$ value for all constructs is presented in Table 6.

Table 6: Coefficient of determination of the latent

\begin{tabular}{|l|c|}
\hline Construct & $R^{2}$ \\
\hline Problem Solving & 0.692 \\
\hline Reasoning & 0.819 \\
\hline Connections & 0.854 \\
\hline Representations & 0.773 \\
\hline Communication & 0.785 \\
\hline Mathematical Process Skills & 0.487 \\
\hline Achievements & 0.758 \\
\hline
\end{tabular}

As shown in Table 6 , the $R^{2}$ value of endogenous variables, problem solving, reasoning, connections, representations, and communication is $0.692,0.819,0.854$, 0.773 , and 0.785 respectively which implies that $69.2 \%$, $81.9 \%, 85.4 \%, 77.3 \%$, and $78.5 \%$ of problem solving, reasoning, connections, representations, and communication respectively are predicted mathematical process skills. Also, the $R^{2}$ for mathematical process skills is 0.487 , which means that $48.7 \%$ of mathematical process skills is explained by teaching kit. Furthermore, $75.8 \%$ of variation in students' mathematics achievement is explained by mathematical process skills and teaching kit. All the $R^{2}$ value in Table 6 is significant at $p<0.001$. In general, the structural model depicts sensibly well the amount of variation explained for each endogenous construct.

\section{Effect size, $f^{2}$}

Apart of the evaluation of $R^{2}$ value, the change of $R^{2}$ value in the endogenous variable, when a specified exogenous variable is excluded from the model can be employed to determine if the deleted exogenous variable has a significant impact on the endogenous construct. This can be achieved by performing $f^{2}$ analysis [24]. The formula for calculating $f^{2}$ [27] is as follows:

$$
f^{2}=\left(R^{2} \text { included }-R^{2} \text { excluded }\right) /\left(1-R^{2} \text { included }\right)
$$

where $R^{2}$ included and $R^{2}$ excluded are the $R$-squares given for the endogenous construct when the exogenous construct
From this analysis, it shows that the correlation between constructs

is used or omitted in the structural model respectively. According to [28], values of $0.02,0.15$ and 0.35 represent the small, medium, and large effects of exogenous variables.

Table 7: Effect size, $f^{2}$

\begin{tabular}{|l|c|c|c|c|}
\hline Construct & $R^{2}$ included & $R^{2}$ excluded & $f^{2}$ & Effect \\
\hline Teaching Kit & \multirow{2}{*}{0.758} & 0.679 & 0.326 & Large \\
\cline { 1 - 4 } \cline { 3 - 5 } Mathematical Process Skills & & 0.517 & 0.996 & Large \\
\hline
\end{tabular}

The result in Table 7 indicates that teaching kit and mathematical process skills have a large effect on students' mathematics achievement.

\section{Predictive relevance}

The predictive relevance of the endogenous variables can be assessed through the $Q^{2}$ test [29]. According to [27], $Q^{2}$ is a measure of how well the observed values are replicated by the model and its estimations of the parameters. In [24] stated that $Q^{2}$ is known to have predictive significance greater than zero. Table 8 shows the value of $Q^{2}$ for all endogenous constructs.

Table 8: $Q^{2}$ value of the latent constructs

\begin{tabular}{|l|c|}
\hline Construct & $Q^{2}$ \\
\hline Problem Solving & 0.450 \\
\hline Reasoning & 0.525 \\
\hline Connections & 0.583 \\
\hline Representations & 0.499 \\
\hline Communication & 0.544 \\
\hline Mathematical Process Skills & 0.404 \\
\hline Achievements & 0.570
\end{tabular}

The study revealed that all the $Q^{2}$ value of the latent constructs is greater than zero. According to [27], $Q^{2}$ value greater than zero is indicative of a predictive relevance, thus the structural model must be able to predict the endogenous latent variables.

\section{CONCLUSION}

The study successfully developed and evaluated the students' achievement model based on mathematical process skills and teaching kit through PLS-SEM. The measurement model and structural model were validated utilizing empirical data and consummate the criterion suggested by [24]. The study revealed that there was significant relationship between mathematical process skills and students' mathematics achievement, and the findings were in tandem with [13], [14] [15]. The results also indicate that the relationship of teaching kit on students' mathematics achievement and mathematical process skills was statistically significant. These findings are in contrast with the previous studies such as [18]-[20]. In conclusions, the results designated that the developed model is strengthen by empirical analysis and in tandem to the antecedent findings and theoretical framework.

\section{ACKNOWLEDGMENT}

The research was funded by Universiti Pendidikan Sultan Idris, Malaysia grant no. 2018-0049-107-0. The researchers would like to acknowledge for the fund provided.

\section{REFERENCES}

1 P. M. Kurup, X. Li, G Powell, and M. Brown, "Building future primary 


\section{DEVELOPMENT AND EVALUATION OF STUDENTS' MATHEMATICS ACHIEVEMENT MODEL THROUGH STRUCTURAL EQUATION MODELLING}

teachers' capacity in STEM: Based on a platform of beliefs, understandings and intentions," International Journal of STEM Education, 6(1), 2019, pp. 1-14.

2 H. Muhonen, A. von Suchodoletz, E. Doering, and J. Kärtner, "Facilitators, teachers, observers, and play partners: Exploring how mothers describe their role in play activities across three communities," Learning, Culture and Social Interaction, 21, 2019, pp. 223-233.

3 K. C. Margot and T. Kettler, "Teachers' perception of STEM integration and education: A systematic literature review," International Journal of STEM Education, 6(1), 2019, pp. 1-16.

4 D. Kim and S. Downey, "Examining the use of the ASSURE model by K-12 teachers," Computers in the Schools, 33(3), 2016, pp. 153-168.

5 D. Fouryza, S. M. Amin, and R. Ekawati, "Review of learning materials development procedure based on fun and easy math (FEM)," AIP Conference Proceedings, 2014(1), 2018, pp. 1-9.

6 K. Higgins, J. Huscroft-D'Angelo, and L.Crawford, "Effects of technology in mathematics on achievement, motivation, and attitude: A meta-analysis," Journal of Educational Computing Research, 57(2), 2019, pp. 283-319.

7 L. Li and B. Gong, "End-to-end video captioning with multitask reinforcement learning," IEEE Winter Conference on Applications of Computer Vision, 2019, pp. 339-348.

8 S. Hilbert, G. Bruckmaier, K. Binder, S. Krauss, and M. Bühner, "Prediction of elementary mathematics grades by cognitive abilities," European Journal of Psychology of Education, 2018, pp. 1-19.

9 Z. Ç. Özcan and A. E. Gümüş, "A modeling study to explain mathematical problem-solving performance through metacognition, self-efficacy, motivation, and anxiety," Australian Journal of Education, 63(1), 2019, pp. 116-134.

10 J. Lee and L. Stankov, "Higher-order structure of noncognitive constructs and prediction of PISA 2003 mathematics achievement," Learning and Individual Differences, 26, 2013, pp. 119-130.

11 H. W. Banse, T. W. Curby, N. A. Palacios, and S. E. RimmKaufman, "How should fifth-grade mathematics teachers start the school year? Relations between teacher-student interactions and mathematics instruction over one year," Teachers College Record, 120(6), 2018, pp. 1-36.

12 H. S. Yi and Y. Lee, "A latent profile analysis and structural equation modeling of the instructional quality of mathematics classrooms based on the PISA 2012 results of Korea and Singapore," Asia Pacific Education Review, 18(1), 2017, pp. 23 39.

13 National Council of Teachers of Mathematics (NCTM), Principles and standards for school mathematics. Virginia: NCTM, 2000

14 National Assessment of Educational Progress (NAEP) Mathematics framework for the 2003 national assessment of educational progress. Washington DC: NAEP, 2003

15 I. V. Mullis, M. O. Martin, G. J. Ruddock, C. Y. O’Sullivan, and C. Preuschoff, TIMSS 2011 assessment frameworks Massachusetts: TIMSS and PIRLS International Study Center, 2012.

16 D. L. Ball and H. Bass, "Making mathematics reasonable in school," in A Research Companion to Principles and Standards for School Mathematics, J. Kilpatrick, W. G. Martin and D. Schifter, Eds.Virginia: National Council of Teachers of Mathematics, 2003, pp. 227-236.

17 K. Brodie, K. Coetzee, and L. Lauf, Teaching Mathematical Reasoning in Secondary School Classrooms. New York Springer, 2010.

18 J. Kilpatrick, J. Swafford, and B. Findell, Adding It Up: Helping Children Learn Mathematics. Washington DC: National Academy Press, 2001.

19 A. K. Barbey and L.W. Barsalou, "Reasoning and problem solving: Models," in Encyclopedia of Neuroscience, L. Squire, Ed. Oxford: Academic Press, 2010, pp. 35-43.

20 H. Çetin and E. Ertekin, "The relationship between eighth grade primary school students' proportional reasoning skills and success in solving equations," International Journal of Instruction, 4(1), 2011, pp. 47-62

21 Kementerian Pendidikan Malaysia, Kurikulum standard sekolah rendah matematik: Dokumen standard kurikulum dan pentaksiran. Putrajaya: Bahagian Pembangunan Kurikulum, 2017

22 G. Polya, How to Solve It: A New Aspect of Mathematical Method. New Jersey: Princeton University Press, 1957.
23 T. Lavender, G. Omoni, R. Laisser, L. McGowan, S. Wakasiaka, G. Maclean, and A. Chimwaza, "Evaluation of an educationa board game to improve use of the partograph in sub-Saharan Africa: A quasi-experimental study," Sexual and Reproductive Healthcare, 20, 2019, pp. 54-59.

24 J. F. Hair, G. T. M. Hult, C. M. Ringle, and M. Sarstedt, A Primer on Partial Least Squares Structural Equation Modelling (PLS-SEM). California: SAGE Publications, 2014.

25 J. F. Hair, W. C. Black, B. J. Babin, and R. E. Anderson, Multivariate Data Analysis. New Jersey: Pearson Prentice Hall, 2010.

26 C. Fornell and D. F. Larcker, "Evaluating structural equation models with unobserable variables and measurement error," Journal of Marketing Research, 18(1), 1981, pp. 39-50.

27 V. E. Vinzi, W. W. Chin, J. Henseler, and H. Wang, Handbook of Partial Least Squares: Concepts, Methods and Applications. Heidelberg: Springer, 2010

28 J. Cohen, "Statistical Power Analysis for the Behavioral Sciences. New Jersey: Lawrence Erlbaum Associates Publishers, 1988

29 M. Stone, "Cross-validatory choice and assessment of statistical predictions," Journal of the Royal Statistical Society, 36(2), 1974, pp. 111-147

\section{AUTHORS PROFILE}

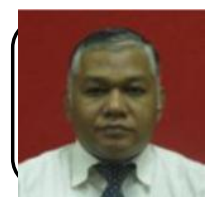

Dr. Zulkifley Mohamed is an associate professor at Universiti Pendidikan Sultan Idris, Malaysia. $\mathrm{He}$ received a degree in Statistics from Universiti Teknolog MARA Malaysia and a master of science in Applied Statistics and Operational Research from University of Salford, UK. He obtained his $\mathrm{PhD}$ degree in Statistics from Universiti Kebangsaan Malaysia. He has been teaching in higher education institutions since 1991 in several subjects such as Probability, Statistics and Research Methodology in Education. His research areas include Robust Statistics, Statistical Modelling and Mathematics Education.

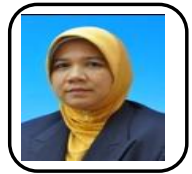

Rosmah Ramli holds a Master degree in mathematics education. She is currently working as a mathematics lecturer at Institut Pendidikan Guru, Ipoh Campus, Malaysia. Her research interest is on higher order thinking skills,innovation in teaching and learning and mathematics education.

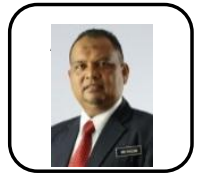

Abu Kassim Ali Musacurrently a lecturer at Institu Pendidikan Guru, Ipoh Campus, Malaysia. He holds Master degree in IT Education from Universiti Pendidikan Sultan Idris Malaysia. His interest in research related to IT, innovation in education and educational technology

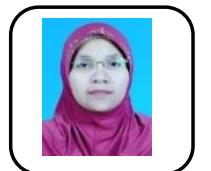

Dr. Norhashimah Abu Bakarcompleted her $\mathrm{PhD}$ (Mathematics Education) at Universiti Pendidikan Sultan Idris Malaysia. Currently, she is a lecturer at Institut Pendidikan Guru, Ipoh Campus, Malaysia. Her research areas include applying structural equation modelling and partial least squares in modelling teaching and learning.

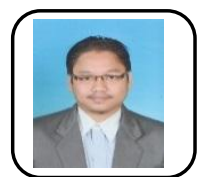

Faiz Zulkifliis a senior lecturer at the Faculty of Computer and Mathematical Sciences of Universiti Teknologi MARA (Perak), Tapah Campus. He holds a degree in Actuarial Sciences from Universiti Kebangsaan Malaysia and further his master degree in Statistics fromUniversiti Malaya. He has 10 years of teaching experience specializing in Statistical Theory and Applied Statistics. 